Article

\title{
Bovines Harbor a Diverse Array of Vector-Borne Pathogens in Northeast Algeria
}

\author{
Ghania Boularias ${ }^{1}$, Naouelle Azzag 1,*, Christelle Gandoin 2 , Corinne Bouillin 2, \\ Bruno Chomel ${ }^{3}$, Nadia Haddad ${ }^{2}$ and Henri-Jean Boulouis ${ }^{2, *}$ \\ 1 Research Laboratory for Local Animal Resources Management (GRAL), National Higher Veterinary School \\ of Algiers, Rue Issad Abbes, El Alia, 16025 Algiers, Algeria; ghania.boularias@gmail.com \\ 2 UMR BIPAR, National Veterinary School of Alfort, Anses, INRAE, Paris-Est University, \\ 7 Avenue du Général de Gaulle, 94700 Maisons-Alfort, France; christelle.gandoin@vet-alfort.fr (C.G.); \\ corinne.bouillin@vet-alfort.fr (C.B.); nadia.haddad@vet-alfort.fr (N.H.) \\ 3 Department of Population Health and Reproduction, School of Veterinary Medicine, University of California, \\ Davis, CA 95616, USA; bbchomel@ucdavis.edu \\ * Correspondence: n.azzag@ensv.dz (N.A.); henri-jean.boulouis@vet-alfort.fr (H.-J.B.)
}

Received: 5 September 2020; Accepted: 23 October 2020; Published: 25 October 2020

check for updates

\begin{abstract}
Arthropod-borne hemoparasites represent a serious health problem in livestock, causing significant production losses. Currently, the evidence of Anaplasma spp., Theileria spp., Babesia spp., and hemotropic Mycoplasma spp. in Algeria remains limited to a few scattered geographical regions. In this work, our objectives were to study the prevalence of these vector-borne pathogens and to search other agents not yet described in Algeria as well as the identification of statistical associations with various risk factors in cattle in the northeast of Algeria. Among the 205 cattle blood samples tested by PCR analysis, $42.4 \%$ positive results were obtained for at least one pathogen. The overall rates of Anaplasma spp., Theileria/Babesia spp., and Mycoplasma spp. in the cattle sampled were respectively $30.7 \%, 18.5 \%$, and $2.9 \%$; co-infections with multiple species was also detected. Anaplasma spp. and Theileria/Babesia spp. were detected at a higher rate in cattle under 3 years old, according to univariate analysis. Anaplasma spp. DNA was detected more frequently in our sample in cattle living in semi extensive farming. Our study provides additional data about Anaplasma spp., Theileria/Babesia spp. and reveals for the first time that Mycoplasma wenyonii and 'Candidatus Mycoplasma hemobos are present in cattle in Northeast Algeria.
\end{abstract}

Keywords: Anaplasma spp.; Theileria spp.; Babesia spp.; hemotropic Mycoplasma spp.; co-infections; PCR; cattle; Algeria

\section{Introduction}

Investigations on the presence and prevalence of bacterial and protozoal pathogenic agents transmitted by arthropods to cattle and the identification of statistical associations with some demographic, breeding, and environmental factors are a prerequisite for a comprehensible explanation of their circulation. These pathogens are unevenly distributed within countries, depending, in particular, on the presence of specific arthropod vectors. Vector-borne diseases are known to cause various symptoms, including a transient mild fever often followed by an alteration in the general health status with hemolytic anemia, anorexia, and abortions, which can lead to death for some animals. These diseases have not only an impact on milk and meat production but on costs of treatment and prevention as well. In addition, apparently asymptomatic or poorly symptomatic infections could have underestimated impacts on cattle production and/or the evolution of coinfections with better-known pathogens $[1,2]$. 
Monitoring of arthropod-borne pathogens (ABP) in bovine populations is important in order to predict the risk of infection in given areas. It allows an early establishment of appropriate control measures. Among ABP, three major groups are of particular veterinary importance: Anaplasma spp., Theileria/Babesia spp., and hemotropic Mycoplasma spp. Climate and other environmental changes are expected to increase the activity and geographic extent of a number of tick species along with the pathogens they carry, consequently increasing the risk of tick-borne diseases in years to come [3].

Currently, there are seven recognized Anaplasma species causing infection in cattle: A. marginale, A. centrale, A. bovis, A. phagocytophilum, A. platys-like, A. capra, and A. ovis [4,5]. All of these are tick-borne, obligatory intracellular, gram-negative bacteria that differ in their host cell tropism. A. marginale, A. centrale, and A. ovis colonize erythrocytes, while A. bovis, A. phagocytophilum, and A. platys infect monocytes, neutrophils, and platelets respectively [6,7]. A. marginale is recognized as the most pathogenic species in cattle [8]. A. centrale is a naturally attenuated species that has been used as a vaccine for the control of bovine anaplasmosis in several countries [9]. A. bovis infection has been reported as asymptomatic; however, it can cause a variety of clinical signs [10]. A. phagocytophilum, A. platys, A. ovis, and the recently identified A. capra are zoonotic species. A. phagocytophilum causes tick-borne fever in cattle and A. platys induce cyclic thrombocytopenia in dogs [11]. A. ovis that primarily infects sheep was detected in humans with symptoms in Cyprus [12]. Recently, A. capra has been identified as the causative agent of anaplasmosis in cattle in China [13].

Genera Theileria and Babesia are widespread tick-borne hemoparasitic pathogens that can induce cattle diseases. Theileria multiplies first in lymphocytes and then in erythrocytes, while Babesia multiplies exclusively in erythrocytes [14]. Cattle can be infected by a large number of species, however, only a few of them can cause clinical signs. T. annulata and T. parva are the most pathogenic species [15]. T. mutans and T. velifera are mildly pathogenic even non-pathogenic species [16]. The subclinical infections by T. orientalis (previously known as T. sergenti, T. buffeli, and T. orientalis) were also reported in cattle [17]. Recently, it has been shown that some genotypes have caused outbreaks in cattle in Japan, Korea, China, Australia, and New Zealand [17]. Among bovine Babesia parasites, clinical signs were mentioned for $B$. bovis, B. bigemina, and B. divergens while only a subclinical infection was described for B. major and B. occultans [18].

Bovine hemoplasmosis is caused by hemotropic Mycoplasma that is an epi-erythrocytic bacteria triggering anemia in infected animals [19]. Two species have been reported in cattle: M. wenyonii and 'Candidatus Mycoplasma hemobos [19,20].

In cattle, the occurrence of tick-borne pathogens directly correlates with the distribution of tick vectors in the area. Indeed, T. annulata transmitted by Hyalomma tick species occurs in the Mediterranean Basin, North-East Africa, Middle East, and South Asia [15], while T. orientalis is present in areas where Haemaphysalis ticks are abundant [17]. Babesia infections are frequent in areas where ticks from the genus Rhipicephalus (Boophilus) predominate. This tick is recognized as the vector of B. bigemina and B. bovis, while the species Ixodes ricinus is the main vector for B. divergens [14]. Several tick species have been associated with the transmission of Anaplasma species, including Ixodes spp., Dermacentor spp., and Rhipicephalus spp. [8,21]. There is no direct evidence that hemotropic Mycoplasma is transmitted by ticks [22], whereas some studies have shown that transmission can occur either via blood-sucking flies or lice or iatrogenically by contaminated needles [23].

The objective of our research was to determine the prevalence of pathogenic species belonging to Anaplasma, Theileria/Babesia, and hemotropic Mycoplasma as well as co-infection cases and to identify statistical associations with some risk factors in cattle. For that, a cross-sectional study, based on PCR analysis, was carried out on blood samples collected from cattle in north-eastern Algeria. 


\section{Results}

\subsection{Molecular Detection of Anaplasma, Theileria/Babesia, and Hemotropic Mycoplasma Species}

PCR-based investigation of 205 cattle showed a total infection rate of $42.4 \%$ (87/205) including both single and coinfection cases. Single, double, and triple infections were identified at the respective rates of (57/205) (27.8\%), 27/205 (13.2\%), and 3/205 (1.4\%) (Table 1).

Table 1. Distribution of single, dual, and triple infection by different species of tick-borne pathogens detected in cattle blood samples.

\begin{tabular}{|c|c|c|c|c|}
\hline & Species & $\begin{array}{l}\text { Number of } \\
\text { Cases }\end{array}$ & Total & Frequency $(\%)$ \\
\hline \multirow{10}{*}{ Singleinfection } & A. centrale & 14 & \multirow{10}{*}{$57 / 205$} & \multirow{10}{*}{27.8} \\
\hline & A. marginale & 2 & & \\
\hline & A.bovis & 1 & & \\
\hline & A.platys & 6 & & \\
\hline & Anaplasma sp. & 3 & & \\
\hline & M. wenyonii & 1 & & \\
\hline & 'Candidatus M. haemobos' & 1 & & \\
\hline & Mycoplasma sp. & 1 & & \\
\hline & Anaplasma/Ehrlichia spp. & 7 & & \\
\hline & Theileria/Babesia spp. & 21 & & \\
\hline \multirow{10}{*}{ Dual infection } & A. centrale, B. occultans & 1 & \multirow{10}{*}{$27 / 205$} & \multirow{10}{*}{13.2} \\
\hline & A. centrale, T. orientalis & 2 & & \\
\hline & A. centrale, Theileria/Babesia spp. & 4 & & \\
\hline & A.centrale, $M$. wenyonii & 1 & & \\
\hline & A. centrale, 'Candidatus M. haemobos' & 1 & & \\
\hline & A. centrale, A. marginale & 11 & & \\
\hline & Uncultured Anaplasma sp., Theileria sp. & 1 & & \\
\hline & Uncultured Anaplasma sp., T. orientalis & 1 & & \\
\hline & $\begin{array}{c}\text { Uncultured Anaplasma sp., } \\
\text { Theileria/Babesia spp. }\end{array}$ & 1 & & \\
\hline & $\begin{array}{c}\text { Anaplasma/Ehrlichia spp., } \\
\text { Theileria/Babesia spp. }\end{array}$ & 4 & & \\
\hline \multirow{3}{*}{$\begin{array}{c}\text { Triple } \\
\text { infection }\end{array}$} & A. centrale, A. marginale, T. annulata & 1 & \multirow{3}{*}{$3 / 205$} & \multirow{3}{*}{1.4} \\
\hline & A. centrale, A. marginale, $T$. orientalis & 1 & & \\
\hline & A. centrale, T. annulata, M. wenyonii & 1 & & \\
\hline & Overall & 87 & $87 / 205$ & 42.4 \\
\hline
\end{tabular}

The overall frequency of Ehrlichia/Anaplasma spp., Theileria/Babesia spp., and Mycoplasma spp. was respectively 30.7\% (63/205), 18.5\% (38/205), and 2.9\% (6/205) (Figure 1). Among the Ehrlichia/Anaplasma spp. detected, A. centrale (37/205, 18\%) was the most frequently recorded species, followed by A. marginale (15/205, 7.3\%) and A. bovis (1/205, 0.5\%), while the DNA of A. phagocytophilum and $A$. capra were not detected. The $16 \mathrm{~S}$ PCR products of $A$. bovis were sequenced and BLAST analysis confirmed $94.84 \%$ identity with $A$. bovis $16 \mathrm{~S}$ gene sequence analyzed (GenBank accession number KX450273.1). The sequencing of Ehrlichia/Anaplasma-positive PCR products that were negative for the presence of the five Anaplasma species mentioned above, revealed 2,9\% (6/205) positive samples for A. platys and 2.9\% (6/205) for uncultured Anaplasma sp. The sequencing of these products showed A 100\% identity with A. platys (GenBank accession number MK386768.1) or uncultured Anaplasma sp. clone AMCRO1 (MN187218.1) respectively. Thirteen samples randomly selected among the 38 cattle (18.5\%) positive samples for Theileria/Babesia DNA were sequenced. Five, four, and two samples were identified as T. annulata, T. orientalis, and Theileria sp. respectively, while a single sample was positive for B. occultans and B. bigemina. All positive PCR products for T. annulata shared $97.6 \%$ sequence identity with GenBank acc. no. MF287924.1, for T. orientalis, 96.7\% with GenBank no. MN187008.1, for Theileria 
sp., 99.4\% with GenBank no. AJ616717.1, for B. occultans, 91.3\% with GenBank no. MK421149.1, and for B. bigemina, 83.3\% with GenBank no. MK732475.1. Among the six samples that were positive for Mycoplasma spp. DNA, three samples were positive for $M$. wenyonii and two for 'Candidatus Mycoplasma hemobos. The DNA sequences of the two identified hemotropic Mycoplasma species showed $98.9 \%$ and $98.5 \%$ identity with those from 'Candidatus Mycoplasma hemobos and M. wenyonii available on GenBank: MG948633.1 and MG948626.1 respectively.

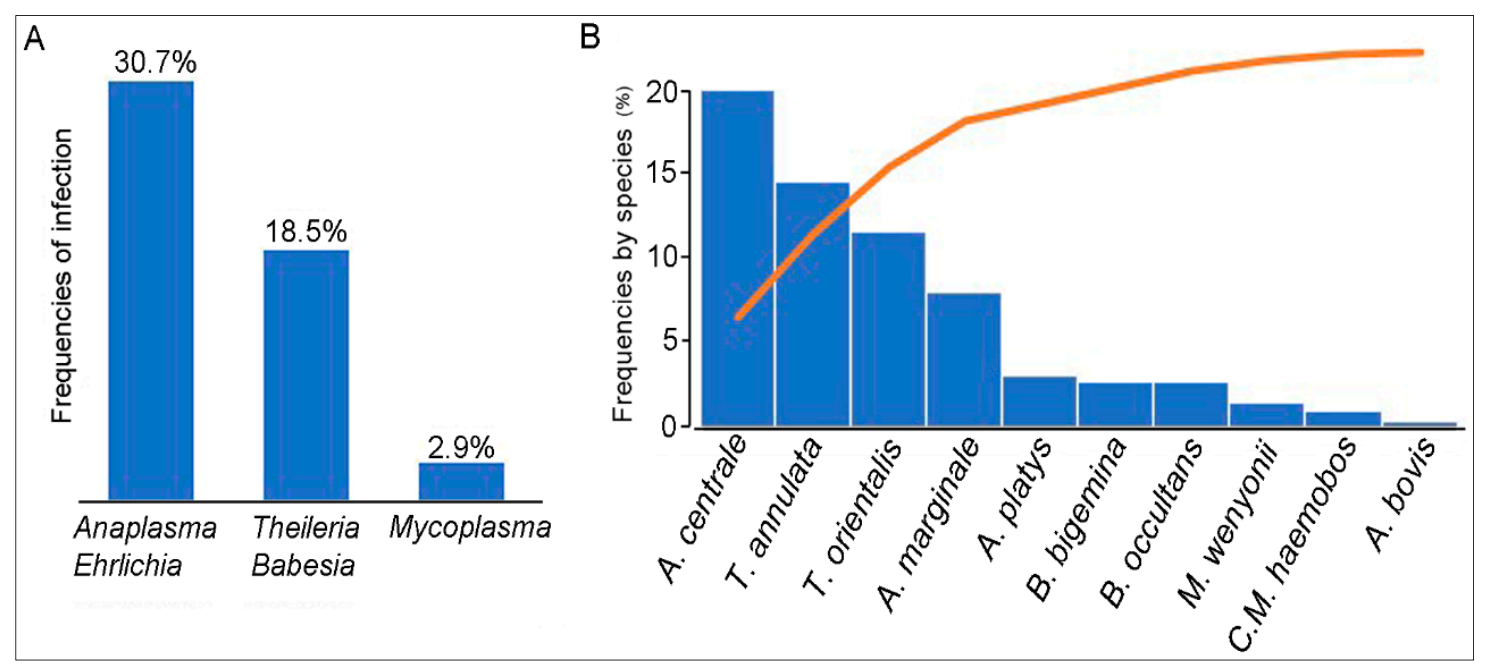

Figure 1. (A) Individual rate of Anaplasma/Ehrlichia spp., Theileria/Babesia spp., and Mycoplasma spp. of 205 cattle tested by PCR. (B) The figure shows in decreasing order the frequencies of each detected species.

\subsection{Variability of Vector-Borne Pathogens Infection Associated to Different Intrinsic and Environmental Factors}

No statistically significant association was observed between the level of Anaplasma and hemotropic Mycoplasma infection and sex of cattle $\left(p\left(\chi^{2}\right)>0.05\right)$, except for Theileria/Babesia, for which a significant difference $\left(p\left(\chi^{2}\right)=0.04\right)$ between males $(8 / 24,33.3 \%)$ and females $(30 / 181,16.5 \%)$ was detected. Cattle under 3 years of age were more frequently infected with Anaplasma spp. $(31 / 75,41 \%)\left(p\left(\chi^{2}\right)=0.02\right)$ and Theileria/Babesia $(20 / 75,26.6 \%)\left(p\left(\chi^{2}\right)=0.02\right)$ than cattle $\geq 3$ years old $(32 / 130,24.6 \%, 18 / 130,13.8 \%)$. For hemotropic Mycoplasma, no statistically significant difference in frequency $\left(p\left(\chi^{2}\right)=0.49\right)$ based on the age of cattle was detected (Table 2). Regarding the farming system, the frequency of Anaplasma spp. infection $(59 / 169,34.9 \%)$ in animals living in semi extensive/extensive farms was significantly higher $\left(p\left(\chi^{2}\right)=0.005\right)$ than cattle raised in intensive production systems $(4 / 36,11.1 \%)$. For Theileria/Babesia and hemotropic Mycoplasma infection, the difference between the farming systems was not statistically significant $\left(p\left(\chi^{2}\right)>0.05\right)$ (Table 2). A significant difference in prevalence $\left(p\left(\chi^{2}\right)=0.004\right)$ between cattle infested with ticks $(42 / 105,40 \%)$ and tick-free cattle $(21 / 100,21 \%)$ was reported for Ehrlichia/Anaplasma spp. only. For Theileria/Babesia spp. and Mycoplasma spp., no significant difference was observed $\left(p\left(x^{2}\right)>0.05\right)$ according to the presence or absence of ticks on the animals. Finally, no significant association was observed between the overall prevalence of tested pathogens and the parasitic load of ticks on the animal (Table 2). 
Table 2. Variability of infection by Ehrlichia/Anaplasma, Theileria/Babesia, and hemotropic Mycoplasma genera associated with gender, age, farming system, and tick infestation in cattle from the studied region.

\begin{tabular}{|c|c|c|c|c|c|c|c|c|c|c|}
\hline \multirow{2}{*}{$\begin{array}{l}\text { Cattle } \\
\text { Group }\end{array}$} & \multirow[b]{2}{*}{ Category } & \multirow{2}{*}{$\begin{array}{c}\text { Number of } \\
\text { Cattle }\end{array}$} & \multicolumn{8}{|c|}{ PCR Results } \\
\hline & & & $\begin{array}{l}\text { Overall } \\
\text { Infection }\end{array}$ & $\begin{array}{l}p\left(\chi^{2}\right) \\
\text { Value }\end{array}$ & $\begin{array}{c}\text { Ehrlichia/ } \\
\text { Anaplasma }\end{array}$ & $\begin{array}{l}p\left(\chi^{2}\right) \\
\text { Value }\end{array}$ & $\begin{array}{l}\text { Theileria/ } \\
\text { Babesia }\end{array}$ & $\begin{array}{l}p\left(\chi^{2}\right) \\
\text { Value }\end{array}$ & $\begin{array}{l}\text { Hemotropic } \\
\text { Mycoplasma }\end{array}$ & $\begin{array}{l}p\left(\chi^{2}\right) \\
\text { Value }\end{array}$ \\
\hline Gender & $\begin{array}{c}\text { Male } \\
\text { Female }\end{array}$ & $\begin{array}{c}24 \\
181\end{array}$ & $\begin{array}{c}12(50 \%) \\
75(41.4 \%)\end{array}$ & 0.4 & $\begin{array}{l}7(29.1 \%) \\
56(31 \%)\end{array}$ & 0.8 & $\begin{array}{c}8(33.3 \%) \\
30(16.5 \%)\end{array}$ & 0.04 & $\begin{array}{l}2(8.3 \%) \\
4(2.2 \%)\end{array}$ & 0.09 \\
\hline Age (year) & $\begin{array}{l}<3 \text { years } \\
\geq 3 \text { years }\end{array}$ & $\begin{array}{c}75 \\
130 \\
\end{array}$ & $\begin{array}{l}41(54.6 \%) \\
46(35.3 \%)\end{array}$ & 0.007 & $\begin{array}{c}31(41 \%) \\
32(24.6 \%)\end{array}$ & 0.02 & $\begin{array}{l}20(26.6 \%) \\
18(13.8 \%)\end{array}$ & 0.02 & $\begin{array}{c}3(4 \%) \\
3(2.3 \%)\end{array}$ & 0.49 \\
\hline $\begin{array}{l}\text { Farming } \\
\text { system }\end{array}$ & $\begin{array}{l}\text { Intensive } \\
\text { Semi/extensive }\end{array}$ & $\begin{array}{c}36 \\
169\end{array}$ & $\begin{array}{c}8(22.2 \%) \\
79(46.7 \%)\end{array}$ & 0.007 & $\begin{array}{c}4(11.1 \%) \\
59(34.9 \%)\end{array}$ & 0.005 & $\begin{array}{c}5(13.8 \%) \\
33(19.5 \%)\end{array}$ & 0.42 & $\begin{array}{c}0 \\
6(3.5 \%)\end{array}$ & 0.24 \\
\hline Ticks & $\begin{array}{l}\text { Present } \\
\text { Absent }\end{array}$ & $\begin{array}{l}105 \\
100\end{array}$ & $\begin{array}{c}50(47.6 \%) \\
37(37 \%)\end{array}$ & 0.14 & $\begin{array}{l}42(40 \%) \\
21(21 \%)\end{array}$ & 0.004 & $\begin{array}{l}20(19 \%) \\
18(18 \%)\end{array}$ & 0.82 & $\begin{array}{c}4(3.8 \%) \\
2(2 \%)\end{array}$ & 0.43 \\
\hline Ticks load & $\begin{array}{c}<10 \\
10-20 \\
>20\end{array}$ & $\begin{array}{c}80 \\
18 \\
7\end{array}$ & $\begin{array}{c}36(45 \%) \\
9(50 \%) \\
5(71.4 \%)\end{array}$ & 0.37 & $\begin{array}{c}30(37.8 \%) \\
8(42.4 \%) \\
4(57.1 \%)\end{array}$ & 0.82 & $\begin{array}{c}14(17.5 \%) \\
4(31.5 \%) \\
2(28.5 \%)\end{array}$ & 0.80 & $\begin{array}{c}3(3.7 \%) \\
1(5.5 \%) \\
0\end{array}$ & 0.80 \\
\hline
\end{tabular}




\section{Discussion}

We carried out a descriptive survey for the determination of infection rates for Ehrlichia/ Anaplasma, Theileria/Babesia, and hemotropic Mycoplasma species in blood samples from bovine collected in north-eastern Algeria, based on DNA detection. While some information concerning the occurrence of bovine anaplasmosis and piroplasmosis had already been reported in Algeria [24-26], the presence of cattle hemoplasmosis (Mycoplasma spp.) had never been documented on the African continent.

This study was carried out in eight municipalities with a cattle population of 44,000 heads, which corresponds approximately to $40 \%$ of the cattle population of the region studied. The low representativity of our sample can be explained by the difficulties encountered in the field, i.e., a very limited access to farms located in isolated and mountainous regions, the difficulty to contain animals that are not used to having frequent contact with humans, and the refusal to cooperate by some breeders. All these factors contributed to the selection bias induced and prevented us from inferring the results to the whole region. Our study reported that $42.4 \%$ of cattle sampled were infected with at least one of the tested vector-borne agents. The high prevalence of these tick-borne pathogens has also been recorded in other countries, such as Ethiopia, China, and Russia $[1,27,28]$. Despite the lack of representativity, our results support an important tick infestation and a significant circulation of tick-borne pathogens in the surveyed region.

Four species of Anaplasma were detected, mainly A. centrale and A. marginale, whereas A. bovis had a low prevalence. These results are in accordance with those of two previous studies carried out in Algeria and Tunisia [25,29]. A. platys, the agent of canine infectious cyclic thrombocytopenia, was detected in $2.9 \%$ of the tested cattle. In other studies, a strain genetically closely related to A. platys called $A$. platys-like was detected in ruminants [24,30,31]. However, our primers were not specific for Anaplasma platys-like. Therefore, A. platys identified in the present study were likely similar to the previously described strains. A. phagocytophilum and A. capra that were not identified in our study. The transmission of A. phagocytophilum is associated with ticks belonging to the Ixodes genus [4]. The population density of I. ricinus in North Africa is mainly restricted to cooler and more humid areas (rainfall of more than $800 \mathrm{~mm}$ per year) of the Mediterranean climatic region, observed in the Atlas mountains [32]. In our study, the I. ricinus tick percentage was only $2.1 \%$, which could explain the absence of $A$. phagocytophilum in the investigated area. The zoonotic $A$. capra species has mainly been described in China [13,33]. As this species has only recently been described, very little data exist in the literature.

The target sequence in the 16S RNA gene of Theileria/Babesia spp. was amplified in $18.5 \%$ of cattle tested. T. annulata was the major species identified (5/13). This species has also been reported as a common pathogen in Tunisia, Spain, Portugal, and Turkey [34-37]. The detection rate of T. orientalis was not negligible either, as 4 out of 13 sequenced specimens tested positive. The frequent occurrence of this species has mostly been associated with cattle from Asia [28,38]. This Theileria species do not harbor high pathogenicity for cattle. However, some outbreaks with severe clinical symptoms have been reported in livestock in Japan, Korea, China, Australia, and New Zealand [17]. B. bigemina and B. occultans DNA were identified in two cattle among the 13 samples sequenced. These two species are transmitted by Rhipicephalus annulatus and Hyalomma marginatum respectively, both known as the most abundant ticks in North Africa [34,39].

Prior to our study, there was no evidence of hemotropic Mycoplasma infection in cattle in Algeria. Therefore, the identification of $M$. wenyonii and 'Candidatus Mycoplasma hemobos in 2.9\% of asymptomatic cattle represents the first report of these pathogens in Algeria. In France, M. wenyonii was detected in cows with clinical symptoms [40]. The epidemiology of bovine hemoplasmosis is poorly understood. Some studies suggest that ticks could represent biological vectors, while, according to other studies, flies, lice, and fleas could ensure a mechanical transmission of this pathogen [41]. Hemotropic Mycoplasma-positive cattle in this study were asymptomatic, which is in agreement with subclinical infections reported by other groups, suggesting that these cattle could be chronic carriers and sources of infection for hemotropic Mycoplasma-negative cattle, newly introduced on farms [41,42]. 
As seen for Anaplasma or Theileria/Babesia infections, this subclinical form can persist for a long period of time after the onset of infection and the affected animals act as reservoirs [21,43].

Cases of co-infection with Anaplasma spp. and Theileria/Babesia spp. were frequently observed in our study. The same circumstances were described by other groups in China (Anaplasma spp., Theileria spp. and Babesia spp.) and in Russia (A. marginale, Theileria spp.) [1,28]. In Japan, authors showed that cattle co-infected with T. orienatlis and Mycoplasma spp. tend to resist infections by other pathogens, as the degree of anemia observed in co-infected animals was significantly milder than in those infected only with T. orientalis. Although the exact mechanism of this phenomenon is unknown, it is possible that the proliferation of T. orientalis is also inhibited by the immune response raised against hemoplasma and/or by several other mechanisms [44]. Further studies are needed to evaluate the host response to co-infections. Nevertheless, it appears that complex clinical manifestations due to a high frequency of co-infections influence the duration of infection and the intensity of the symptoms, which subsequently affects the effective control of diseases [1].

The association of a higher rate of infection with Theileria/Babesia spp. in male cattle $\left(p\left(\chi^{2}\right)=0.04\right)$ suggests that animal gender could play a role in the receptivity to these pathogens, as reported by Zhou et al. [28]. In addition, the higher Anaplasma spp., Theileria/Babesia spp., and hemotropic Mycoplasma spp. infection rates in cattle younger than 3 years may be associated with repeated exposures of cattle to these pathogens, allowing cattle to develop protective immunity. In general, a higher frequency for the pathogens investigated was observed in cattle living in semi extensive and extensive livestock $\left(46.7 \%, p\left(\chi^{2}\right)=0.007\right)$. There is no doubt that semi and extensive farming potentially increased the risk for cattle to be exposed to tick bites, the probability of tick infection being increased by their proximity with infected wild animals, especially reservoir species.

\section{Materials and Methods}

\subsection{Ethical Statement}

The sample collection was authorized by the National Veterinary School of Algiers, Algeria, and the agreement of the Veterinary Services Department of the Wilaya of Tizi-Ouzou, Algeria. All cattle were sampled according to Algerian regulations. Blood collection was performed under owners' presence and standard techniques for collecting blood samples were used, respecting animal welfare.

\subsection{Sampling and DNA Extraction}

The study was conducted in the Tizi-Ouzou region, a city located in the Northeast of Algeria. The total number of cattle is 110,000 heads, spread over 66 municipalities (data from the Tizi-Ouzou Agricultural Services). For the sampling plan, we proceeded as follows: out of a total of 66 municipalities, 8 were selected, which corresponded to $40 \%$ (44, 000 heads) of the bovine livestock and $12.1 \%$ of the region studied (Figure 2). This selection was established according to the possibilities of access to the farms. Then, 205 cattle apparently healthy were selected from 35 farms as follows: in each farm, a maximum of 10 cattle was randomly sampled from herds of 10 or more. For herds of less than 10 cattle, all animals were sampled. Blood samples were collected from the caudal vein of cattle between May 2015 and November 2017. A standardized questionnaire was used to obtain information regarding farm management practices and possible risk factors associated with infection with ABP. Information about age and sex was also recorded. For data analysis, two age groups were constituted to compare animals less than 3 years old to older animals. The 3 years cut off was based on the age at first calving. The presence of ticks was recorded; identification was carried out to the genus. The parasitic load is the total number of ticks collected from the sampled cattle (Table 2). A total of 810 ixodid ticks were collected from 105 cattle and belonged to 3 different genera after morphological identification using taxonomic keys developed by Walker et al. [32]: Rhipicephalus $(\mathrm{n}=491)$, Hyalomma $(\mathrm{n}=302)$, and Ixodes $(\mathrm{n}=17)$. The Table S1 contains the data of each individual animal; date of blood sampled, Sex, age, farming system, number and genera of collected ticks and identified pathogens. 
A

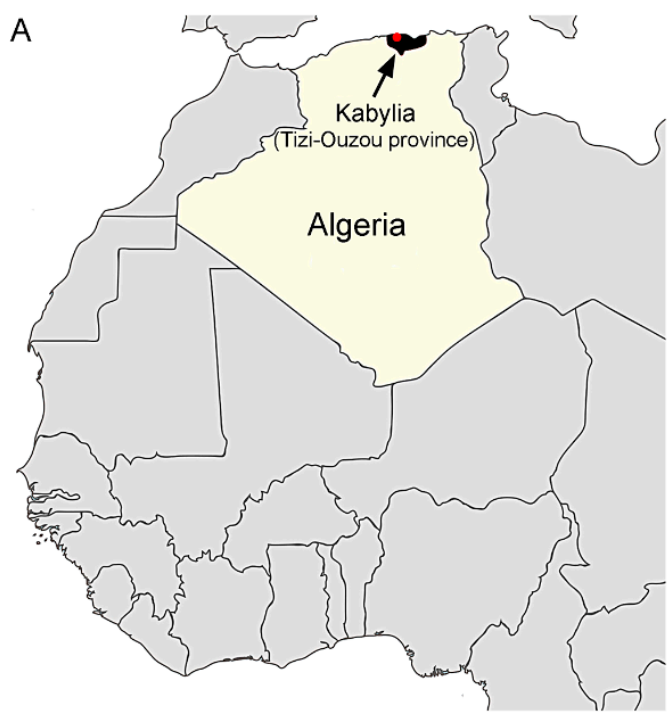

\section{B}

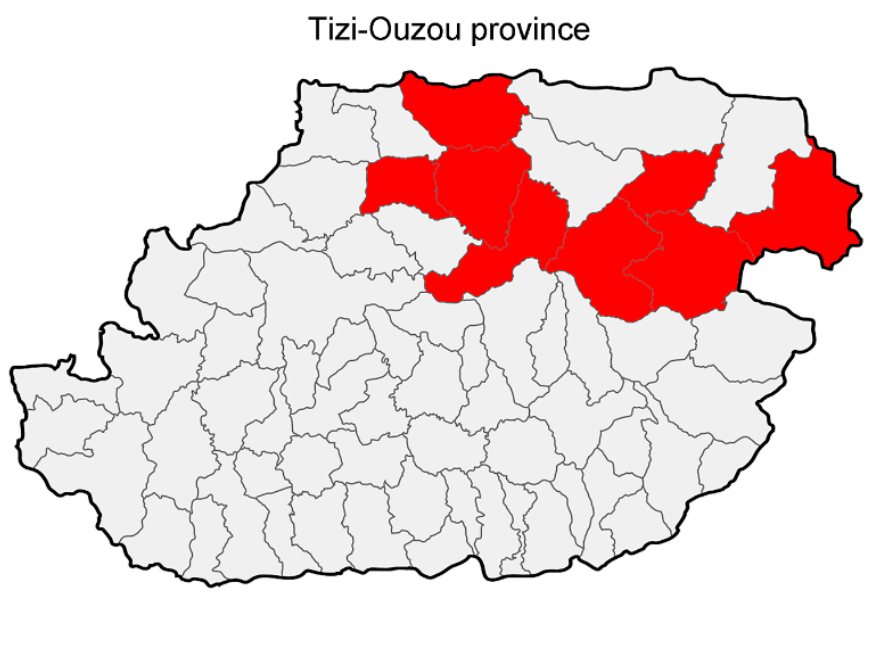

Figure 2. Map of Tizi-Ouzou city (Algeria); (A) geographical location of the sample collection; (B) elements colored in red correspond to the 8 municipalities selected.

DNA was extracted from whole blood samples using a $200 \mu$ L EDTA Nucleospin Blood Quickpure kit (NucleoSpin $₫$, Macherey-Nagel, Düren, Germany) according to the manufacturer's instructions. DNA samples were stored at $-20^{\circ} \mathrm{C}$ until analyzed by PCR.

\subsection{Molecular Detection of Ehrlichia/Anaplasma, Theileria/Babesia, and Hemotropic Mycoplasma species}

Extracted DNAs were used as templates for initial standard PCR targeting the 16S RNA gene (Table 3) to detect Ehrlichia/Anaplasma spp. [45], Theileria/Babesia spp. [46], and Mycoplasma spp. [47]. The samples that were positive for Ehrlichia/Anaplasma spp. were further investigated for the presence of A. marginale, A. centrale, A. bovis, A. capra, and A. phagocytophilum DNA. The presence of A. marginale DNA was investigated by amplifying the gene encoding the major surface protein 1 ( $m s p 1$, Table 3 ). For the detection of A. centrale, A. bovis, and A. capra DNA, PCR tests were performed with primers for the genes encoding $16 \mathrm{~S}$ RNA (Table 3). Standard $25 \mu \mathrm{L}$ volume PCRs containing $5 \mu \mathrm{L}$ of DNA template were performed using Taq polymerase (Takara Ex Taq, Dalian, China). PCR products were visualized in $2 \%$ agarose gel, containing ethidium bromide. A. phagocytophilum, Babesia caballi and Mycoplasma haemofelis DNAs were used as positive controls for the detection of Ehrlichia/Anaplasma spp., Theileria/Babesia spp., and Mycoplasma spp., respectively. To monitor the occurrence of false-positive PCR results, negative controls ( $20 \mu \mathrm{L}$ of reaction mixture $+5 \mu \mathrm{L}$ of ultrapure water) were included for each amplification. In order to minimize contaminations, the DNA extraction, the reagent set-up, the DNA addition, the PCR, and the sample analysis were performed in four separate rooms.

Detection of $A$. phagocytophilum was performed using primers for the $m s p 2$ gene (Table 3). The real-time PCR assay for the detection of A. phagocytophilum was carried out and the analysis of the results was performed using Light Cycler $₫ 480$ Software Version 1.5.1. (Roche Applied Science, Penzberg, Germany). For the Ehrlichia/Anaplasma-positive DNA samples that were found to be negative for five Anaplasma species, a nested PCR test targeting the Ehrlichia 16S rRNA gene (Table 3) was performed, followed by sequencing (Eurofins, Ivry-sur-Seine, France, https://Cochin.eurofins.com) of the amplicon. To detect the Theileria/Babesia and Mycoplasma species, a PCR test targeting the 16S rRNA gene (Table 3) was carried out and the positive PCR products were sequenced (Eurofins). The obtained sequences were analyzed using BioEdit and blasted against online available nucleotide databases in NCBI (https://www.ncbi.nlm.nih.gov). 
Table 3. List of pathogens, target genes, name and sequences of primers/probes used in this study, hybridization temperature $\left(\mathrm{T}{ }^{\circ} \mathrm{C}\right.$ ), and length of fragments (pb) amplified by PCR.

\begin{tabular}{|c|c|c|c|c|c|c|}
\hline Pathogen & Target Gene & Primer Name & Sequence $\left(5^{\prime}-3^{\prime}\right)$ & Hybridization $\left(\mathrm{T}^{\circ} \mathrm{C}\right)$ & Length $(\mathrm{pb})$ & Reference \\
\hline \multirow{2}{*}{$\begin{array}{l}\text { Ehrlichial } \\
\text { Anaplasma }\end{array}$} & \multirow{2}{*}{ RNA $16 S$} & EHR1 16S F & GGTACCYACAGAAGAAGTCC & \multirow{2}{*}{52} & \multirow{2}{*}{346} & \multirow{2}{*}{ [45] } \\
\hline & & EHR1 16S R & TAGCACTCATCGTTTACAGC & & & \\
\hline \multirow{4}{*}{$\begin{array}{l}\text { Nested PCR } \\
\text { Ehrlichial } \\
\text { Anaplasma }\end{array}$} & \multirow{4}{*}{ RNA $16 S$} & EHR1 F & GAACGAACGCTGGCGGCAAGC & \multirow{2}{*}{60} & \multirow{2}{*}{693} & \multirow{4}{*}{ [48] } \\
\hline & & EHR2 R & AGTA(T/C)CG(A/G)ACCAGATAGCCGC & & & \\
\hline & & EHR3 F & TGCATAGGAATCTACCTAGTAG & \multirow{2}{*}{55} & \multirow{2}{*}{592} & \\
\hline & & EHR2 R & AGTA(T/C)CG(A/G)ACCAGATAGCCGC & & & \\
\hline \multirow{3}{*}{$\begin{array}{c}\text { qPCR A. } \\
\text { phagocytophilum }\end{array}$} & \multirow{3}{*}{$m s p 2$} & APH F & ATG GAA GGT AGT GTT GGT TAT GGT ATT & \multirow{3}{*}{60} & \multirow{3}{*}{77} & \multirow{3}{*}{ [49] } \\
\hline & & APH R & TTG GTC TTG AAG CGC TCG TA & & & \\
\hline & & APH P & TGG TGC CAG GGT TGA GCT TGA GAT TG & & & \\
\hline \multirow{2}{*}{ A. marginale } & \multirow{2}{*}{$m s p 1$} & Msp1 a F & TGTGCTTATGGCAGACATTTCC & \multirow[b]{2}{*}{55} & \multirow[b]{2}{*}{1224} & \multirow[b]{2}{*}{ [50] } \\
\hline & & Msp1 a R & AAACCTTGTAGCCCAACTTATCC & & & \\
\hline \multirow[b]{2}{*}{ A. centrale } & \multirow[b]{2}{*}{ RNA $16 S$} & AC1f & CTGCTTTTAATACTGCAGGACTA & \multirow[b]{2}{*}{55} & \multirow[b]{2}{*}{426} & \multirow{4}{*}{ [51] } \\
\hline & & AC1r & ATGCAGCACCTGTGAGGT & & & \\
\hline \multirow{2}{*}{ A. bovis } & \multirow{2}{*}{ RNA $16 S$} & $\mathrm{AB} 1 \mathrm{~F}$ & CTCGTAGCTTGCTATGAGAAC & \multirow{2}{*}{55} & \multirow{2}{*}{551} & \\
\hline & & AB1 R & TCTCCCGGCTCCAGTCTG & & & \\
\hline \multirow{2}{*}{ A. capra } & \multirow{2}{*}{ RNA $16 S$} & A. capra $\mathrm{F}$ & GCAAGTCGAACGGACCAAATCTGT & \multirow{2}{*}{58} & \multirow{2}{*}{1261} & [52] \\
\hline & & A. capra $\mathrm{R}$ & CCACGATTACTAGCGATTCCGACTTC & & & \\
\hline Mycoplasma & RNA $16 S$ & GP03 F & GGGAGCAAACA GGATTAGATA & 55 & 280 & [47] \\
\hline & & MGSO R & TGCACCATCTGTCACTCTGTTAACCTC & & & \\
\hline Theileria/Babesia & RNA $16 S$ & RLB-F & GAGGTAGTGACAAGAAATAACAATA & 50 & 502 & [46] \\
\hline & & RLB-R & TCTTCGATCCCCTAACTTTC & & & \\
\hline
\end{tabular}




\subsection{Statistical Analysis}

The Pearson Chi-square $\left(\chi^{2}\right)$ for univariate analyses was calculated using SPSS statistics 20 software (IBM SPSS Statistics 20, France) to assess the association of the frequencies of pathogens with demographic and environmental factors. $p$ values $\leq 0.05$ were evaluated as statistically significant.

\section{Conclusions}

In conclusion, this study revealed the circulation of at least ten species of vector-borne pathogens in cattle sampled in the Northeast of Algeria with the first detection of M. wenyonii and 'Candidatus Mycoplasma hemobos. Several co-infections were noticed. Such cases could have a clinical impact, which affects the effective surveillance and control programs of these diseases. Although our sample was not representative, the diversity of the detected agents and the high frequency for some of them suggest a great abundance of vector-borne agents in the area studied. These results highlight the need for effective control measures to prevent the transmission of tick-borne pathogens to cattle in Algeria.

Supplementary Materials: The following are available online at http://www.mdpi.com/2076-0817/9/11/883/s1, Table S1: This table contains the data of each individual animal; date of blood sampled, Sex, age, farming system, number and genera of collected ticks and identified pathogens.

Author Contributions: Conceptualization, G.B., H.-J.B. and N.A.; methodology, G.B., H.-J.B., N.A., N.H., B.C., C.G. and C.B.; software, G.B.; validation, H.-J.B., N.H. and N.A.; formal analysis, G.B.; investigation, G.B.; resources, H.-J.B.; data curation, G.B.; writing—original draft preparation, G.B.; writing-review and editing, G.B., N.A., H.-J.B., N.H. and B.C.; visualization, H.-J.B.; supervision, N.A., H.-J.B.; project administration, N.A., H.-J.B.; funding acquisition, H.-J.B., N.A. All authors have read and agreed to the published version of the manuscript.

Funding: This research was supported by UMR BIPAR, Maisons-Alfort, France.

Acknowledgments: The authors would like to thank the Ministry of Scientific Research and Higher Education of Algeria and laboratory Management of Local Animal Resources (GRAL) at the National Veterinary School of Algiers for funding laboratory for the research. We would like to acknowledge the farmers who accepted to participate in the study and Clotilde Rouxel for her assistance during the laboratory manipulations.

Conflicts of Interest: The authors declare no conflict of interest. The funders had no role in the design of the study; in the collection, analyses, or interpretation of data; in the writing of the manuscript, or in the decision to publish the results.

\section{References}

1. Bursakov, S.A.; Kovalchuk, S.N. Co-infection with tick-borne disease agents in cattle in Russia. Ticks Tick Borne Dis. 2019, 10, 709-713. [CrossRef]

2. Ghafar, A.; Cabezas-Cruz, A.; Galon, C.; Obregon, D.; Gasser, R.B.; Moutailler, S.; Jabbar, A. Bovine ticks harbour a diverse array of microorganisms in Pakistan. Parasit. Vectors 2020, 13, 1. [CrossRef]

3. Bouchard, C.; Dibernardo, A.; Koffi, J.; Wood, H.; Leighton, P.; Lindsay, L. Augmentation du risque de maladies transmises par les tiques dans le contexte des changements climatiques et environnementaux. Relev. Mal. Transm. Canada. 2019, 45, 89-98. [CrossRef]

4. Battilani, M.; de Arcangeli, S.; Balboni, A.; Dondi, F. Genetic diversity and molecular epidemiology of Anaplasma. Infect. Genet. Evolut. 2017, 49, 195-211. [CrossRef] [PubMed]

5. Yan, Y.; Jiang, Y.; Tao, D.; Zhao, A.; Qi, M.; Ning, C. Molecular detection of Anaplasma spp. in dairy cattle in southern Xinjiang, China. Vet. Parasitol. Reg. Stud. Reports. 2020, 20, 10040. [CrossRef] [PubMed]

6. Dumler, J.S.; Barbet, A.F.; Cornelis, P.J.; Bekker, C.P.J.; Dasch, G.A.; Palmer, G.H.; Ray, S.C.; Rikihisa, Y.; Rurangirwa, F.R. Reorganization of genera in the families Rickettsiaceae and Anaplasmataceae in the order Rickettsiales: Unification of some species of Ehrlichia with Anaplasma, Cowdria with Ehrlichia and Ehrlichia with Neorickettsia, descriptions of six new species. Combi. Int. J. Syst. Evolut. Microbiol. 2001, 51, 2145-2165. [CrossRef] [PubMed]

7. Ochirkhuu, N.; Konnai, S.; Odbileg, R.; Murata, S.; Ohashi, K. Molecular epidemiological survey and genetic characterization of Anaplasma species in Mongolian Livestock. Vector Borne Zoonotic Dis. 2017, 17, 539-549. [CrossRef] 
8. Kocan, K.M.; de la Fuente, J.; Blouin, E.F.; Coetzee, J.F.; Ewing, S.A. The natural history of Anaplasma marginale. Vet. Parasitol. 2010, 167, 95-107. [CrossRef]

9. Byaruhanga, C.; Collins, N.E.; Knobel, D.L.; Khumalo, Z.T.H.; Chaisi, M.E.; Oosthuizen, M.C. Molecular detection and phylogenetic analysis of Anaplasma marginale and Anaplasma centrale amongst transhumant cattle in north-eastern Uganda. Ticks Tick Borne Dis. 2018, 9, 580-588. [CrossRef]

10. Noaman, V. Molecular detection of Anaplasma bovis in Cattle from central part of Iran. Vet. Res. Forum 2010, 1, 117-122.

11. Abarca, K.; López, J.; Perret, C.; Guerrero, J.; Godoy, P.; Echeverría, A.V.F.; León, U.; Gutjahr, C.; Azócar, T. Anaplasma platys in Dogs, Chile. Emerg. Infect. Dis. 1990, 13, 1392-1395. [CrossRef] [PubMed]

12. Dimosthenis, C.; Ioannis, I.; Tselentis, Y.; Psaroulaki, A. Human anaplasmosis and Anaplasma ovis variant. Emerg. Infect. Dis. 2010, 16, 1031-1032. [CrossRef]

13. Li, H.; Zheng, Y.C.; Ma, L.; Jia, N.; Jiang, B.G.; Jiang, R.R.; Huo, Q.B.; Wang, Y.W.; Liu, H.B.; Chu, Y.L.; et al. Human infection with a novel tick-borne Anaplasma species in China: A surveillance study. Lancet Infect. Dis. 2015, 15, 663-670. [CrossRef]

14. Chauvin, A.; Moreau, E.; Bonnet, S.; Plantard, O.; Malandrin, L. Babesia and its hosts: Adaptation to long-lasting interactions as a way achieve efficient transmission. Vet. Res. 2009, 40, 37-40. [CrossRef] [PubMed]

15. Nene, V.; Morrison, W.I. Approaches to vaccination against Theileria parva and Theileria annulata. Parasite Immunol. 2016, 38, 724-734. [CrossRef] [PubMed]

16. Lorusso, V.; Wijnveld, M.; Majekodunmi, A.O.; Dongkum, C.; Fajinmi, A.; Dogo, A.G.; Thrusfield, M.; Mugenyi, A.; Vaumourin, E.; Igweh, A.C.; et al. Tick-borne pathogens of zoonotic and veterinary importance in Nigerian cattle. Parasites Vectors 2016, 9, 1-13. [CrossRef] [PubMed]

17. Bogema, D.R.; Micallef, M.L.; Liu, M.; Padula, M.P.; Djordjevic, S.P.; Darling, A.E.; Jenkins, C. Analysis of Theileria orientalis draft genome sequences reveals potential species-level divergence of the ikeda, chitose and buffeli genotypes. BMC Genom. 2018, 19, 298. [CrossRef] [PubMed]

18. Aktas, M.; Ozubek, S. Molecular and parasitological survey of bovine piroplasms in the black sea region, including the first report of babesiosis associated with Babesia divergens in Turkey. J. Med. Entomol. 2015, 52, 1344-1350. [CrossRef]

19. Neimark, H.; Johansson, K.E.; Rikihisa, Y.; Tully, J.G. Proposal to transfer some members of the genera Haemobartonella and Eperythrozoon to the genus Mycoplasma with descriptions of 'Candidatus Mycoplasma haemofelis', 'Candidatus Mycoplasma haemomuris', 'Candidatus Mycoplasma haemosuis' and 'Candidatus Mycoplasma wenyonii'. Int. J. Syst. Evolut. Microbiol. 2001, 51, 891-899. [CrossRef]

20. Tagawa, M.; Yamakawa, K.; Aoki, T.; Matsumoto, K.; Ishi, M.; Inokuma, H. Effect of chronic Hemoplasma infection on cattle productivity. J. Vet. Med. Sci. 2013, 75, 1271-1275. [CrossRef]

21. Aubry, P.; Geale, D.W. A review of bovine anaplasmosis. Transbound. Emerg. Dis. 2011, 58, 1-30. [CrossRef] [PubMed]

22. Ayling, R.D.; Bisgaard-Frantzen, S.; Adler, A.; Blowey, R.W.; Barlow, A.M.; Millar, M.F.; van der Burgt, G.M. Detection of "Candidatus Mycoplasma haemobos", Mycoplasma wenyonii and Anaplasma phagocytophilum from Cattle in England. Vet. Rec. 2012, 170, 21. [CrossRef] [PubMed]

23. Hornok, S.; Micsutka, A.; Meli, M.L.; Lutz, H.; Hofmann-Lehmann, R. molecular investigation of transplacental and vector-borne transmission of bovine Haemoplasmas. Vet. Microbiol. 2011, 152, 411-414. [CrossRef]

24. Dahmani, M.; Davoust, B.; Benterki, M.S.; Fenollar, F.; Raoult, D.; Mediannikov, O. Development of a new PCR-based assay to detect Anaplasmataceae and the first report of Anaplasma phagocytophilum and Anaplasma platys in cattle from algeria. Comp. Immunol. Microbiol. Infect. Dis. 2015, 39, 39-45. [CrossRef] [PubMed]

25. Rjeibi, M.R.; Ayadi, O.; Rekik, M.; Gharbi, M. Molecular survey and genetic characterization of Anaplasma centrale, A. marginale and A. bovis in cattle from algeria. Trans Bound. Emerg. Dis. 2018, 65, 456-464. [CrossRef]

26. Ziam, H.; Kelanamer, R.; Aissi, M.; Ababou, A.; Berkvens, D.; Geysen, D. Prevalence of bovine theileriosis in north central region of Algeria by real-time polymerase chain reaction with a note on its distribution. Trop. Anim. Health Prod. 2015, 47, 787-796. [CrossRef] [PubMed]

27. Hailemariam, Z.; Krucken, J.; Baumann, M.; Ahmed, J.S.; Peter-Henning Clausen, J.P.; Ard, M.; Nijhof, A.M. Molecular detection of tick-borne pathogens in cattle from Southwestern Ethiopia. PLoS ONE 2017, 17, 1-16. [CrossRef] [PubMed] 
28. Zhou, Z.; Li, K.; Sun, Y.; Shi, J.; Li, H.; Chen, Y.; Yang, H.; Li, X.; Wu, B.; Li, Z.; et al. Molecular epidemiology and risk factors of Anaplasma Spp., Babesia Spp. and Theileria Spp. infection in Cattle in Chongqing, China. PLoS ONE 2019, 14, e0215585. [CrossRef]

29. Belkahia, H.; Ben Said, M.; El Mabrouk, N.; Saidani, M.; Cherni, C.; Ben Hassen, M.; Bouattour, A.; Messadi, L. Spatio-temporal variations and genetic diversity of Anaplasma Spp. in Cattle from the North of Tunisia. Vet. Microbiol. 2017, 208, 223-230. [CrossRef]

30. Zobba, R.; Anfossi, A.G.; Parpaglia, M.L.P.; Dore, G.M.; Chessa, B.; Spezzigu, A.; Rocca, S.; Visco, S.; Pittau, M.; Alberti, A. Molecular investigation and phylogeny of Anaplasma spp. in Mediterranean ruminants reveal the presence of neutrophil-tropic strains closely related to A. platys. Appl. Environ. Microbiol. 2014, 80, 271-280. [CrossRef]

31. Ben Said, M.; Belkahia, H.; El Mabrouk, N.; Saidani, M.; Alberti, A.; Zobba, R.; Cherifa, A.; Mahjoub, T.; Bouattour, A.; Messadi, L. Anaplasma platys-like strains in ruminants from Tunisia. Infect. Genet. Evolut. 2017, 49, 226-233. [CrossRef] [PubMed]

32. Walker, A.R.; Bouattour, A.; Camicas, J.; Estrada-Peña, A.; Horak, I.; Latif, A.; Pegram, R.; Preston, P. Ticks of domestic animals in Africa: A guide to identification of species. In Bioscience Reports; The University of Edinburgh: Edinburgh, UK, 2003; pp. 1-221.

33. Seo, M.G.; Ouha, I.O.; Lee, H.; Geraldino, P.J.L.; Rhee, M.H.; Kwon, O.D.; Kwak, D. Differential Identification of Anaplasma in cattle and potential of cattle to serve as reservoirs of Anaplasma capra, an emerging tick-borne zoonotic pathogen. Vet. Microbiol. 2018, 226, 15-22. [CrossRef]

34. M'ghirbi, Y.; Hurtado, A.; Brandika, J.; Khlif, K.; Ketata, Z.; Bouattour, A. A molecular survey of Theileria and Babesia Parasites in Cattle, with a note on the distribution of ticks in Tunisia. Parasitol. Res. 2008, 103, 435-442. [CrossRef] [PubMed]

35. Calleja-Bueno, L.; Sainz, Á.; García-Sancho, M.; Rodríguez-Franco, F.; González-Martín, J.V.; Villaescusa, A. Ticks and tick-borne diseases molecular, epidemiological, haematological and biochemical evaluation in asymptomatic Theileria annulata infected cattle from an endemic region in Spain. Ticks Tick Borne Dis. 2017, 8, 936-941. [CrossRef]

36. Gomes, J.; Salgueiro, P.; Inácio, J.; Amaro, A.; Pinto, J.; Tait, A.; Shiels, B.; da Fonseca, I.P.; Santos-Gomes, G.; Weir, W. Population diversity of Theileria annulata in Portugal. Infect. Genet. Evolut. 2016, 42, 14-19. [CrossRef] [PubMed]

37. Dumanli, N.; Aktas, M.; Cetinkaya, B.; Cakmak, A.; Koroglu, E.; Saki, C.E.; Erdogmus, Z.; Nalbantoglu, S.; Ongor, H.; Simsek, S.; et al. Prevalence and distribution of tropical theileriosis in Eastern Turkey. Vet. Parasitol. 2005, 127, 9-15. [CrossRef]

38. Aktaş, M.; Kısadere, İ.; Özübek, S.; Cihan, H.; Salıkov, R.; Cirak, Y.V. First molecular survey of Piroplasm species in Cattle from Kyrgyzstan. Parasitol. Res. 2019, 118, 2431-2435. [CrossRef]

39. Benchikh Elfegoun, M.C.; Gharbi, M.; Djebir, S.; Kohil, K. Dynamique d'activité saisonnière des tiques ixodidés parasites des bovins dans deux étages bioclimatiques du nord-est algérien. Rev. D'élev. Méd. Vétér. Pays Trop. 2013, 66, 117-122. [CrossRef]

40. Nouvel, L.X.; Hygonenq, M.C.; Catays, G.; Martinelli, E.; le Page, P.; Collin, É.; Inokuma, H.; Schelcher, F.; Citti, C.; Maillard, R. First detection of Mycoplasma wenyonii in France: Identification, evaluation of the clinical impact and development of a new specific detection assay. Comp. Immunol. Microbiol. Infect. Dis. 2019, 63, 148-153. [CrossRef]

41. Ybañez, A.P.; Ybañez, R.H.D.; Armonia, R.K.M.; Chico, J.K.E.; Ferraren, K.J.V.; Tapdasan, E.P.; Salces, C.B.; Maurillo, B.C.A.; Galon, E.M.S.; Macalanda, A.M.C.; et al. First molecular detection of Mycoplasma wenyonii and the ectoparasites biodiversity in dairy water buffalo and cattle in Bohol, Philippines. Parasitol. Int. 2019, 70,77-81. [CrossRef]

42. Girotto, A.; Zangirólamo, A.F.; Bogado, A.L.G.; Souza, A.S.L.; da Silva, G.C.F.; Garcia, J.L.; Boas, L.A.V.; Biondo, A.W.; Vidotto, O. Molecular detection and occurrence of 'Candidatus Mycoplasma haemobos' in Dairy Cattle of Southern Brazil. Rev. Bras. Parasitol. Vet. 2012, 21, 342-344. [CrossRef] [PubMed]

43. Brown, W.C.; Norimine, J.; Knowles, D.P.; Goff, W.L. Immune control of Babesia bovis infection. Vet. Parasitol. 2006, 138, 75-87. [CrossRef] [PubMed]

44. Tagawa, M.; Ybanez, A.P.; Matsumotoa, K.; Yokoyama, N.; Inokuma, H. Interference between Theileria orientalis and hemotropic Mycoplasma spp. (Hemoplasmas) in grazing cattle. Vet. Parasitol. 2013, 195, 165-168. [CrossRef] [PubMed] 
45. Parola, P.; Cornet, J.; Ose, Y.; Miller, R.S.; Thien, H.V.; Gonzalez, J.P. Detection of Ehrlichia spp., Anaplasma spp., Rickettsia spp., and other eubacteria in ticks from the Thai-Myanmar border and Vietnam. J. Clin. Microbiol. 2003, 41, 1600-1608. [CrossRef]

46. Gubbels, J.M.; de Vos, A.P.; van der Weide, M.; Viseras, J.; Schouls, L.M.; de Vries, E.; Jongejan, F. Simultaneous detection of bovine Theileria and Babesia species by reverse line blot hybridization. J. Clin. Microbiol. 1999, 37, 1782-1789. [CrossRef]

47. Van Kuppeveld, F.J.M.; van der Logt, J.T.M.; Angulo, A.F.; van Zoest, M.J.; Quint, W.G.V.; Niesters, H.G.M.; Galama, J.M.D.; Melchers, W.J.G. Genus- and species-specific identification of Mycoplasmas by 16S rRNA amplification. Appl. Environ. Microbiol. 1992, 58, 2606-2615. [CrossRef]

48. Rar, V.A.; Fomenko, N.V.; Dobrotvorsky, A.K.; Livanova, N.H.; Rudakova, S.A.; Fedorov, E.G.; Astanin, V.B.; Morozova, O.V. Tick borne pathogen detection, Western Siberia, Russia. Emerg. Infect. Dis. 2005, 11, 1708-1715. [CrossRef]

49. Courtney, J.W.; Kostelnik, L.M.; Zeidner, N.S.; Massung, R.F. Multiplex real-time PCR for detection of Anaplasma phagocytophilum and Borrelia burgdorferi. J. Clin. Microbiol. 2004, 42, 3164-3168. [CrossRef]

50. Lew, A.E.; Bock, R.E.; Minchin, C.M.; Masaka, S. A Msp1 $\alpha$ polymerase chain reaction assay for specific detection and differentiation of Anaplasma marginale isolates. Vet. Microbiol. 2002, 86, 325-335. [CrossRef]

51. Kawahara, M.; Rikihisa, Y.; Lin, Q.; Isogai, E.; Tahara, K.; Itagaki, A.; Hiramitsu, Y.; Tajima, T. Novel genetic variants of Anaplasma phagocytophilum, Anaplasma bovis, Anaplasma centrale, and a Novel Ehrlichia sp. in wild deer and ticks on two major islands in Japan. Appl. Environ. Microbiol. 2006, 72, 1102-1109. [CrossRef]

52. Yang, J.; Liu, Z.; Niu, Q.; Liu, J.; Han, R.; Liu, G.; Shi, Y.; Luo, J.; Yin, H. Molecular survey and characterization of a novel Anaplasma species closely related to Anaplasma capra in Ticks, Northwestern China. Parasites Vectors 2016, 9, 9-13. [CrossRef] [PubMed]

Publisher's Note: MDPI stays neutral with regard to jurisdictional claims in published maps and institutional affiliations. 